\title{
Melanocortin 4 Receptor Deficiency
}

National Cancer Institute

\section{Source}

National Cancer Institute. Melanocortin 4 Receptor Deficiency. NCI Thesaurus. Code C120394.

Deficiency or dysfunction of the melanocortin 4 receptor, associated with loss-offunction mutation(s) in the MCFR4 gene. 